\title{
Potentiometric and Thermodynamic Studies of Some Schiff-Base Derivatives of 4-Aminoantipyrine and Their Metal Complexes
}

\author{
A. A. El-Bindary, A. Z. El-Sonbati, M. A. Diab, and M. K. Abd El-Kader \\ Department of Chemistry, Faculty of Science, Damietta University, Damietta 34517, Egypt \\ Correspondence should be addressed to A. A. El-Bindary; abindary@yahoo.com
}

Received 12 June 2012; Accepted 20 September 2012

Academic Editor: Dimosthenis L. Giokas

Copyright (c) 2013 A. A. El-Bindary et al. This is an open access article distributed under the Creative Commons Attribution License, which permits unrestricted use, distribution, and reproduction in any medium, provided the original work is properly cited.

The proton-ligand dissociation constant of 4-(4-amino-1,5-dimethyl-2-phenyl-1,2-dihydro-pyrazol-3-ylideneamino)-phenol ( $\left.\mathrm{L}_{1}\right)$ and 4-(4-amino-1,5-dimethyl-2-phenyl-1,2-dihydro-pyrazol-3-ylideneamino)-benzoic acid $\left(\mathrm{L}_{2}\right)$ and metal-ligand stability constants of their complexes with metal ions $\left(\mathrm{Mn}^{2+}, \mathrm{Co}^{2+}, \mathrm{Ni}^{2+}\right.$, and $\left.\mathrm{Cu}^{2+}\right)$ have been determined potentiometrically in $0.1 \mathrm{~mol} \cdot \mathrm{dm}^{-3}$ $\mathrm{KCl}$ and $10 \%$ (by volume) ethanol-water mixture and at 298, 308, and $318 \mathrm{~K}$. The stability constants of the formed complexes increase in the order $\mathrm{Mn}^{2+}, \mathrm{Co}^{2+}, \mathrm{Ni}^{2+}$, and $\mathrm{Cu}^{2+}$. The effect of temperature was studied, and the corresponding thermodynamic parameters $(\Delta G, \Delta H$, and $\Delta S)$ were derived and discussed. The dissociation process is nonspontaneous, endothermic, and entropically unfavourable. The formation of the metal complexes has been found to be spontaneous, endothermic, and entropically favourable.

\section{Introduction}

Schiff-base coordination complexes have attracted great attention over the past decades due not only to their facile syntheses, their wide application, and the accessibility of diverse structural modifications, but also to their biological modeling applications, catalysis, design of molecular ferromagnets, and materials chemistry [1-6]. It is well known that $\mathrm{N}$ atoms play a key role in the coordination of metals at the active sites of numerous metallobiomolecules [7]. The Schiff bases of 4-aminoantipyrine and their coordination complexes have been extensively investigated because of their biological, clinical, pharmacological, analytical and material applications [8-11]. Also some drugs showed increased activity when administered as metal chelate rather than as free organic compounds $[12,13]$. In continuation of earlier work [14-18], we report here the dissociation constant of 4-(4-amino-1,5-dimethyl-2-phenyl1,2-dihydro-pyrazol-3-ylideneamino)-phenol $\left(\mathrm{L}_{1}\right)$ and 4-(4amino-1,5-dimethyl-2-phenyl-1,2-dihydro-pyrazol-3-ylideneamino)-benzoic acid $\left(\mathrm{L}_{2}\right)$ and the stability constants of their complexes with $\mathrm{Mn}^{2+}, \mathrm{Co}^{2+}, \mathrm{Ni}^{2+}$, and $\mathrm{Cu}^{2+}$ at different temperatures. Furthermore, the corresponding thermodynamic functions of complexation are evaluated and discussed.

\section{Experimental}

4-(4-Amino-1,5-dimethyl-2-phenyl-1,2-dihydro-pyrazol-3ylideneamino)-phenol $\left(\mathrm{L}_{1}\right)$ and 4-(4-amino-1,5-dimethyl2-phenyl-1,2-dihydro-pyrazol-3-ylideneamino)-benzoic acid $\left(\mathrm{L}_{2}\right)$ (Figure 1) were prepared by refluxing a mixture of hot solution of 4 -aminoantipyrine $(0.1 \mathrm{mmol})$ and 4 hydroxyaniline or 4-carboxyaniline $(0.1 \mathrm{mmol})$ in $50 \mathrm{~cm}^{3}$ ethanol for $2 \mathrm{~h}[19,20]$. The formed solid product was separated by filtration, purified by crystallization from ethanol, washed with diethyl ether, and dried in a vacuum over anhydrous calcium chloride.

A ligand solution $\left(0.001 \mathrm{~mol} \cdot \mathrm{dm}^{-3}\right)$ was prepared by dissolving an accurately weighed amount of the solid in ethanol (Analar). Metal ion solutions $\left(0.0001 \mathrm{~mol} \cdot \mathrm{dm}^{-3}\right)$ were prepared from Analar metal chlorides in bidistilled water and standardized with EDTA [20]. Solutions of $0.001 \mathrm{~mol} \cdot \mathrm{dm}^{-3}$ $\mathrm{HCl}$ and $1 \mathrm{~mol} \cdot \mathrm{dm}^{-3} \mathrm{KCl}$ were also prepared in bidistilled water. A carbonate-free sodium hydroxide solution in $10 \%$ 
<smiles>Cc1c(N)/c(=N/c2ccc(O)cc2)n(-c2ccccc2)n1C</smiles>

$\left(\mathrm{L}_{1}\right)$

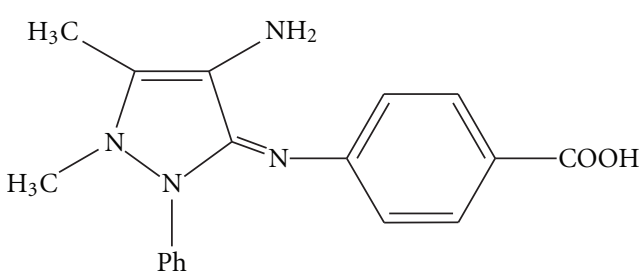

$\left(\mathrm{L}_{2}\right)$

Figure 1

TABLE 1: Thermodynamic functions for the dissociation of ligand $\left(\mathrm{L}_{1}\right)$ in $10 \%$ (by volume) ethanol-water mixture and $0.1 \mathrm{~mol} \cdot \mathrm{dm}^{-3}$ $\mathrm{KCl}$ at different temperatures.

\begin{tabular}{ccccc}
\hline$T / \mathrm{K}$ & $\begin{array}{c}\text { Dissociation } \\
\text { constant } \\
\mathrm{pK}^{\mathrm{H}}\end{array}$ & $\begin{array}{c}\text { Gibbs energy } \\
\mathrm{kJ} \cdot \mathrm{mol}^{-1} \\
\Delta G_{1}\end{array}$ & $\begin{array}{c}\text { Enthalpy } \\
\mathrm{kJ} \cdot \mathrm{mol}^{-1} \\
\Delta H_{1}\end{array}$ & $\begin{array}{c}\text { Entropy } \\
\mathrm{J} \cdot \mathrm{mol}^{-1} \cdot \mathrm{K}^{-1} \\
-\Delta S_{1}\end{array}$ \\
\hline 298 & $9.25(0.10)$ & 52.77 & & 70.56 \\
308 & $9.07(0.09)$ & 53.48 & 31.75 & 70.57 \\
318 & $8.90(0.09)$ & 54.19 & & 70.56 \\
\hline
\end{tabular}

Standard deviations are given in parentheses.

TABLE 2: Thermodynamic functions for the dissociation of ligand $\left(\mathrm{L}_{2}\right)$ in $10 \%$ (by volume) ethanol-water mixture and $0.1 \mathrm{~mol} \cdot \mathrm{dm}^{-3}$ $\mathrm{KCl}$ at different temperatures.

\begin{tabular}{ccccc}
\hline$T / \mathrm{K}$ & $\begin{array}{c}\text { Dissociation } \\
\text { constant } \\
\mathrm{pK}^{\mathrm{H}}\end{array}$ & $\begin{array}{c}\text { Gibbs energy } \\
\mathrm{kJ} \cdot \mathrm{mol}^{-1}\end{array}$ & $\begin{array}{c}\text { Enthalpy } \\
\mathrm{kJ} \cdot \mathrm{mol}^{-1}\end{array}$ & $\begin{array}{c}\text { Entropy } \\
\mathrm{J} \cdot \mathrm{mol}^{-1} \cdot \mathrm{K}^{-1} \\
\end{array}$ \\
\hline 298 & $4.26(0.09)$ & 24.31 & & $-\Delta S_{1}$ \\
308 & $4.09(0.09)$ & 24.12 & 31.73 & 24.92 \\
318 & $3.91(0.08)$ & 23.81 & & 24.72 \\
\hline
\end{tabular}

Standard deviations are given in parentheses.

(by volume) ethanol-water mixture was used as titrant and standardized against oxalic acid (Analar).

The apparatus, general conditions, and methods of calculation were the same as in previous work [1518]. The following mixtures (i)-(iii) were prepared and titrated potentiometrically at $298 \mathrm{~K}$ against standard $0.002 \mathrm{~mol} \cdot \mathrm{dm}^{-3} \mathrm{NaOH}$ in a $10 \%$ (by volume) ethanol-water mixture:

(i) $5 \mathrm{~cm}^{3} 0.001 \mathrm{~mol} \cdot \mathrm{dm}^{-3} \mathrm{HCl}+5 \mathrm{~cm}^{3} 1 \mathrm{~mol} \cdot \mathrm{dm}^{-3} \mathrm{KCl}+$ $5 \mathrm{~cm}^{3}$ ethanol.

(ii) $5 \mathrm{~cm}^{3} 0.001 \mathrm{~mol} \cdot \mathrm{dm}^{-3} \mathrm{HCl}+5 \mathrm{~cm}^{3} 1 \mathrm{~mol} \cdot \mathrm{dm}^{-3} \mathrm{KCl}+$ $5 \mathrm{~cm}^{3} 0.001 \mathrm{~mol} \cdot \mathrm{dm}^{-3}$ ligand.

(iii) $5 \mathrm{~cm}^{3} 0.001 \mathrm{~mol} \cdot \mathrm{dm}^{-3} \mathrm{HCl}+5 \mathrm{~cm}^{3} 1 \mathrm{~mol} \cdot \mathrm{dm}^{-3}$ $\mathrm{KCl}+5 \mathrm{~cm}^{3} 0.001 \mathrm{~mol} \cdot \mathrm{dm}^{-3}$ ligand $+10 \mathrm{~cm}^{3}$ $0.0001 \mathrm{~mol} \cdot \mathrm{dm}^{-3}$ metal chloride.

For each mixture, the volume was made up to $50 \mathrm{~cm}^{3}$ with bidistilled water before the titration. These titrations were repeated for temperatures of $308 \mathrm{~K}$ and $318 \mathrm{~K}$. The temperature was controlled to within $\pm 0.05 \mathrm{~K}$ by circulating thermostated water (Neslab 2 RTE 220) through the outer jacket of the vessel. The $\mathrm{pH}$ measurements were performed with a Metrohm 836 Titrando (KF \& Potentiometric Titrator) equipped with a combined porolyte electrode. The $\mathrm{pH}$ meter readings in the nonaqueous medium were corrected [21]. The electrode system was calibrated according to the method of Irving et al. [22]. All titrations have been carried out between $\mathrm{pH} 3.0$ and 11.0 and under nitrogen atmosphere.

\section{Results and Discussion}

The average number of the protons associated with ligands $\left(\mathrm{L}_{1}\right.$ and $\left.\mathrm{L}_{2}\right)$ at different $\mathrm{pH}$ values, $\bar{n}_{A}$, was calculated from the titration curves of the acid in the absence and presence of ligands $\left(\mathrm{L}_{1}\right.$ and $\left.\mathrm{L}_{2}\right)$. Apply (1):

$$
\bar{n}_{A}=Y+\frac{\left(V_{1}-V_{2}\right)\left(N^{0}+E^{0}\right)}{\left(V^{0}+V_{1}\right) T C_{L}^{0}}
$$

where $Y$ is the number of available protons in ligands $\left(\mathrm{L}_{1}\right.$ and $\left.\mathrm{L}_{2}\right)(Y=1)$ and $V_{1}$ and $V_{2}$ are the volumes of alkali required to reach the same $\mathrm{pH}$ on the titration curve of hydrochloric acid and reagent, respectively, $V^{0}$ is the initial volume $\left(50 \mathrm{~cm}^{3}\right)$ of the mixture, $T C_{L}^{0}$ is the total concentration of the reagent, $N^{0}$ is the normality of sodium hydroxide solution, and $E^{0}$ is the initial concentration of the free acid. Thus, the formation curves $\left(\bar{n}_{A}\right.$ versus $\left.\mathrm{pH}\right)$ for the proton-ligand systems were constructed and found to extend between 0 and 1 in the $\bar{n}_{A}$ scale. This means that ligands $\left(\mathrm{L}_{1}\right.$ and $\left.\mathrm{L}_{2}\right)$ have one ionizable proton (the enolized hydrogen ion of the $-\mathrm{OH}$ and $-\mathrm{COOH}$ group, $\mathrm{pK}^{\mathrm{H}}$ ), respectively. Different computational methods [23] were applied to evaluate the dissociation constant. Three replicate titrations were performed; the average values obtained are listed in Tables 1 and 2. The completely protonated form of ligands $\left(\mathrm{L}_{1}\right.$ and $\left.\mathrm{L}_{2}\right)$ has one dissociable proton that dissociates in the measurable $\mathrm{pH}$ range.

The formation curves for the metal complexes were obtained by plotting the average number of ligands attached per metal ion $(\bar{n})$ versus the free ligands exponent $(\mathrm{pL})$, according to Irving and Rossotti [24]. The average number 
TABLE 3: Stepwise stability constants for $\mathrm{ML}$ and $\mathrm{ML}_{2}$ complexes of ligand $\left(\mathrm{L}_{1}\right)$ in $10 \%$ (by volume) ethanol-water mixtures and $0.1 \mathrm{~mol} \cdot \mathrm{dm}^{-3}$ $\mathrm{KCl}$ at different temperatures.

\begin{tabular}{|c|c|c|c|c|c|c|}
\hline \multirow{2}{*}{$\mathrm{M}^{n+}$} & \multicolumn{2}{|c|}{$298 \mathrm{~K}$} & \multicolumn{2}{|c|}{$308 \mathrm{~K}$} & \multicolumn{2}{|c|}{$318 \mathrm{~K}$} \\
\hline & $\log K_{1}$ & $\log K_{2}$ & $\log K_{1}$ & $\log K_{2}$ & $\log K_{1}$ & $\log K_{2}$ \\
\hline $\mathrm{Mn}^{2+}$ & $6.84(0.08)$ & $6.04(0.11)$ & $7.02(0.09)$ & $6.22(0.10)$ & $7.19(0.10)$ & $6.40(0.11)$ \\
\hline $\mathrm{Co}^{2+}$ & $6.95(0.09)$ & $6.13(0.10)$ & $7.13(0.09)$ & $6.31(0.10)$ & $7.31(0.11)$ & $6.48(0.11)$ \\
\hline $\mathrm{Ni}^{2+}$ & $7.02(0.09)$ & $6.19(0.09)$ & $7.20(0.10)$ & $6.37(0.09)$ & $7.38(0.11)$ & $6.54(0.10)$ \\
\hline $\mathrm{Cu}^{2+}$ & $7.15(0.09)$ & $6.34(0.09)$ & $7.34(0.09)$ & $6.52(0.10)$ & $7.53(0.11)$ & $6.70(0.10)$ \\
\hline
\end{tabular}

Standard deviations are given in parentheses.

TABLE 4: Stepwise stability constants for $\mathrm{ML}$ and $\mathrm{ML}_{2}$ complexes of ligand $\left(\mathrm{L}_{2}\right)$ in $10 \%$ (by volume) ethanol-water mixtures and $0.1 \mathrm{~mol} \cdot \mathrm{dm}^{-3}$ $\mathrm{KCl}$ at different temperatures.

\begin{tabular}{|c|c|c|c|c|c|c|}
\hline \multirow{2}{*}{$\mathrm{M}^{n+}$} & \multicolumn{2}{|c|}{$298 \mathrm{~K}$} & \multicolumn{2}{|c|}{$308 \mathrm{~K}$} & \multicolumn{2}{|c|}{$318 \mathrm{~K}$} \\
\hline & $\log K_{1}$ & $\log K_{2}$ & $\log K_{1}$ & $\log K_{2}$ & $\log K_{1}$ & $\log K_{2}$ \\
\hline $\mathrm{Mn}^{2+}$ & $7.33(0.08)$ & $6.74(0.09)$ & $7.50(0.09)$ & $6.90(0.10)$ & $7.67(0.10)$ & $7.07(0.10)$ \\
\hline $\mathrm{Co}^{2+}$ & $7.54(0.09)$ & $6.85(0.10)$ & $7.72(0.10)$ & $7.02(0.10)$ & $7.90(0.10)$ & $7.20(0.11)$ \\
\hline $\mathrm{Ni}^{2+}$ & $7.63(0.09)$ & $6.92(0.10)$ & $7.80(0.11)$ & $7.10(0.09)$ & $7.98(0.11)$ & $7.27(0.10)$ \\
\hline $\mathrm{Cu}^{2+}$ & $7.78(0.09)$ & $7.07(0.10)$ & $7.97(0.10)$ & $7.26(0.10)$ & $8.16(0.11)$ & $7.44(0.10)$ \\
\hline
\end{tabular}

Standard deviations are given in parentheses.

of the reagent molecules attached per metal ion, $\bar{n}$, and free ligands exponent, pL, can be calculated using (2) and:

$$
\begin{gathered}
\bar{n}=\frac{\left(V_{3}-V_{2}\right)\left(N^{0}+E^{0}\right)}{\left(V^{0}+V_{2}\right) \bar{n}_{A} T C_{M}^{0}}, \\
\mathrm{pL}=\log _{10} \frac{\sum_{n=0}^{n=J} \beta_{n}^{\mathrm{H}}[1 / \operatorname{anti} \log \mathrm{pH}]^{n}}{T C_{L}^{0}-\bar{n} T C_{M}^{0}} \cdot \frac{V^{0}+V_{3}}{V^{0}},
\end{gathered}
$$

where $T C_{M}^{0}$ is the total concentration of the metal ion present in the solution and $\beta_{n}^{\mathrm{H}}$ is the overall proton-reagent stability constant. $V_{1}, V_{2}$, and $V_{3}$ are the volumes of alkali required to reach the same $\mathrm{pH}$ on the titration curves of hydrochloric acid, organic ligand, and complex, respectively. These curves were analyzed, and the successive metal-ligand stability constants were determined using different computational methods $[25,26]$. The values of the stability constants $\left(\log K_{1}\right.$ and $\log K_{2}$ ) are given in Tables 3 and 4 . The following general remarks can be pointed out.

(i) The maximum value of $\bar{n}$ was $\sim 2$ indicating the formation of $1: 1$ and $1: 2$ (metal: ligand) complexes only [27].

(ii) The metal ion solution used in the present study was very dilute $\left(2 \times 10^{-5} \mathrm{~mol} \cdot \mathrm{dm}^{-3}\right)$; hence there was no possibility of formation of polynuclear complexes [28, 29].

(iii) The metal titration curves were displaced to the righthand side of the ligand titration curves along the volume axis, indicating proton release upon complex formation of the metal ion with the ligand. The large decrease in $\mathrm{pH}$ for the metal titration curves relative to ligand titration curves points to the formation of strong metal complexes $[30,31]$. (iv) For the same ligand at constant temperature, the stability of the chelates increases in the order $\mathrm{Mn}^{2+}$, $\mathrm{Co}^{2+}, \mathrm{Ni}^{2+}$, and $\mathrm{Cu}^{2+}[19,32,33]$. This order largely reflects that the stability of $\mathrm{Cu}^{2+}$ complexes is considerably larger than those of other metals of the $3 \mathrm{~d}$ series. Under the influence of both the polarizing ability of the metal ion [34] and the ligand field [35] $\mathrm{Cu}^{2+}$ will receive some extra stabilization due to tetragonal distortion of octahedral symmetry in its complexes. The greater stability of $\mathrm{Cu}^{2+}$ complexes is produced by the well-known Jahn-Teller effect [35].

The dissociation constant $\left(\mathrm{pK}^{\mathrm{H}}\right)$ for ligands $\left(\mathrm{L}_{1}\right.$ and $\left.\mathrm{L}_{2}\right)$, as well as the stability constants of its complexes with $\mathrm{Mn}^{2+}$, $\mathrm{Co}^{2+}, \mathrm{Ni}^{2+}$, and $\mathrm{Cu}^{2+}$, has been evaluated at $298 \mathrm{~K}, 308 \mathrm{~K}$, and $318 \mathrm{~K}$ and is given in Tables $1,2,5$, and 6 , respectively. The enthalpy $(\Delta H)$ for the dissociation and complexation process was calculated from the slope of the plot $\mathrm{pK}^{\mathrm{H}}$ or $\log$ $K$ versus $1 / T$ using the graphical representation of van't Hoff equations (3) and (4):

$$
\Delta G=-2.303 R T \log K=\Delta H-T \Delta S,
$$

or

$$
\log K=\left(\frac{-\Delta H}{2.303 R}\right)\left(\frac{1}{T}\right)+\left(\frac{\Delta S}{2.303 R}\right) .
$$

From the $\Delta G$ and $\Delta H$ values one can deduce the entropy $\Delta S$ using the well-known relationships (3) and (5):

$$
\Delta S=\frac{(\Delta H-\Delta G)}{T} .
$$

All thermodynamic parameters of the dissociation process of ligands $\left(\mathrm{L}_{1}\right.$ and $\left.\mathrm{L}_{2}\right)$ are recorded in Tables 1 and 2 . From these results the following conclusions can be made. 
TABLE 5: Thermodynamic functions for $\mathrm{ML}$ and $\mathrm{ML}_{2}$ complexes of ligand $\left(\mathrm{L}_{1}\right)$ in $10 \%$ (by volume) ethanol-water mixture and $0.1 \mathrm{~mol} \cdot \mathrm{dm}{ }^{-3}$ $\mathrm{KCl}$.

\begin{tabular}{|c|c|c|c|c|c|c|c|}
\hline \multirow{2}{*}{$\mathrm{M}^{n+}$} & \multirow{2}{*}{$\mathrm{T} / \mathrm{K}$} & \multicolumn{2}{|c|}{ Gibbs energy $/ \mathrm{kJ} \cdot \mathrm{mol}^{-1}$} & \multicolumn{2}{|c|}{ Enthalpy $/ \mathrm{kJ} \cdot \mathrm{mol}^{-1}$} & \multicolumn{2}{|c|}{ Entropy $/ \mathrm{J} \cdot \mathrm{mol}^{-1} \cdot \mathrm{K}^{-1}$} \\
\hline & & $-\Delta G_{1}$ & $-\Delta G_{2}$ & $\Delta H_{1}$ & $\Delta H_{2}$ & $\Delta S_{1}$ & $\Delta S_{2}$ \\
\hline \multirow{3}{*}{$\mathrm{Mn}^{2+}$} & 298 & 39.03 & 34.46 & & & 237.52 & 225.21 \\
\hline & 308 & 41.39 & 36.68 & 31.75 & 32.65 & 237.50 & 225.10 \\
\hline & 318 & 43.78 & 38.97 & & & 237.52 & 225.21 \\
\hline \multirow{3}{*}{$\mathrm{Co}^{2+}$} & 298 & 39.66 & 34.98 & & & 242.64 & 223.92 \\
\hline & 308 & 42.05 & 37.21 & 32.64 & 31.75 & 242.52 & 223.91 \\
\hline & 318 & 44.51 & 39.46 & & & 242.64 & 223.92 \\
\hline \multirow{3}{*}{$\mathrm{Ni}^{2+}$} & 298 & 40.06 & 35.32 & & & 243.98 & 225.07 \\
\hline & 308 & 42.46 & 37.57 & 32.65 & 31.75 & 243.87 & 225.06 \\
\hline & 318 & 44.94 & 39.82 & & & 243.98 & 225.07 \\
\hline \multirow{3}{*}{$\mathrm{Cu}^{2+}$} & 298 & 40.79 & 36.18 & & & 252.55 & 230.96 \\
\hline & 308 & 43.29 & 38.45 & 34.46 & 32.65 & 252.43 & 230.84 \\
\hline & 318 & 45.85 & 40.79 & & & 252.55 & 230.96 \\
\hline
\end{tabular}

TABLE 6: Thermodynamic functions for $\mathrm{ML}$ and $\mathrm{ML}_{2}$ complexes of ligand $\left(\mathrm{L}_{2}\right)$ in $10 \%$ (by volume) ethanol-water mixture and $0.1 \mathrm{~mol} \cdot \mathrm{dm}{ }^{-3}$ $\mathrm{KCl}$.

\begin{tabular}{|c|c|c|c|c|c|c|c|}
\hline \multirow{2}{*}{$\mathrm{M}^{n+}$} & \multirow{2}{*}{$T / K$} & \multicolumn{2}{|c|}{ Gibbs energy $/ \mathrm{kJ} \cdot \mathrm{mol}^{-1}$} & \multicolumn{2}{|c|}{ Enthalpy $/ \mathrm{kJ} \cdot \mathrm{mol}^{-1}$} & \multicolumn{2}{|c|}{ Entropy $/ \mathrm{J} \cdot \mathrm{mol}^{-1} \cdot \mathrm{K}^{-1}$} \\
\hline & & $-\Delta G_{1}$ & $-\Delta G_{2}$ & $\Delta H_{1}$ & $\Delta H_{2}$ & $\Delta S_{1}$ & $\Delta S_{2}$ \\
\hline \multirow{3}{*}{$\mathrm{Mn}^{2+}$} & 298 & 41.82 & 38.46 & & & 243.82 & 229.45 \\
\hline & 308 & 44.23 & 40.69 & 30.83 & 29.92 & 243.72 & 229.25 \\
\hline & 318 & 46.70 & 43.05 & & & 243.82 & 229.45 \\
\hline \multirow{3}{*}{$\mathrm{Co}^{2+}$} & 298 & 43.02 & 39.09 & & & 253.93 & 237.64 \\
\hline & 308 & 45.53 & 41.39 & 32.65 & 31.73 & 253.82 & 237.44 \\
\hline & 318 & 48.01 & 43.83 & & & 253.93 & 237.65 \\
\hline \multirow{3}{*}{$\mathrm{Ni}^{2+}$} & 298 & 43.54 & 39.48 & & & 252.58 & 239.05 \\
\hline & 308 & 45.99 & 41.87 & 31.73 & 31.75 & 252.38 & 239.04 \\
\hline & 318 & 48.59 & 44.27 & & & 252.58 & 239.05 \\
\hline \multirow{3}{*}{$\mathrm{Cu}^{2+}$} & 298 & 44.39 & 40.34 & & & 264.61 & 248.00 \\
\hline & 308 & 47.48 & 42.81 & 34.46 & 33.56 & 264.50 & 247.99 \\
\hline & 318 & 49.68 & 45.30 & & & 264.62 & 248.05 \\
\hline
\end{tabular}

(i) The $\mathrm{pK}^{\mathrm{H}}$ values decrease with increasing temperature; that is, the acidity of the ligand increases [17].

(ii) A positive value of $\Delta H$ indicates that the process is endothermic.

(iii) A large positive value of $\Delta G$ indicates that the dissociation process is not spontaneous [36].

(iv) A negative value of $\Delta S$ is obtained due to the increased order as a result of the solvation process.

All the thermodynamic parameters of the stepwise stability constants of complexes are recorded in Tables 5 and 6 . It is known that the divalent metal ions exist in solution as octahedrally hydrated species [26], and the obtained values of $\Delta H$ and $\Delta S$ can then be considered as the sum of two contributions: (a) release of $\mathrm{H}_{2} \mathrm{O}$ molecules and (b) metalligand bond formation. Examination of these values shows the following. (i) The stability constants $\left(\log K_{1}\right.$ and $\left.\log K_{2}\right)$ for ligands $\left(\mathrm{L}_{1}\right.$ and $\left.\mathrm{L}_{2}\right)$ complexes increase with increasing temperature; that is, its stability constants increase with increasing temperature [37].

(ii) The negative value of $\Delta G$ for the complexation process suggests the spontaneous nature of such processes [38].

(iii) The $\Delta H$ values are positive, meaning that these processes are endothermic and favourable at higher temperature.

(iv) The $\Delta S$ values for the ligand complexes are positive, confirming that the complex formation is entropically favourable [16].

\section{References}

[1] S. Kotha, "The building block approach to unusual alpha-amino acid derivatives and peptides," Accounts of Chemical Research, vol. 36, no. 5, pp. 342-351, 2003. 
[2] M. J. O'Donnell, "The enantioselective synthesis of $\alpha$-amino acids by phase-transfer catalysis with achiral Schiff base esters," Accounts of Chemical Research, vol. 37, pp. 506-517, 2004.

[3] H.-C. Wu, P. Thanasekaran, C.-H. Tsai et al., "Self-assembly, reorganization, and photophysical properties of silver(I)-Schiffbase molecular rectangle and polymeric array species," Inorganic Chemistry, vol. 45, pp. 295-303, 2006.

[4] M. Zhao, C. Zhong, C. Stern, A. G. M. Barrett, and B. M. Hoffman, "Synthesis and magnetic properties comparison of $\mathrm{M}-\mathrm{Cu}(\mathrm{II})$ and $\mathrm{M}-\mathrm{VO}(\mathrm{II})$ Schiff base-porphyrazine complexes: what is the mechanism for spin-coupling?" Journal of the American Chemical Society, vol. 127, no. 27, pp. 9769-9775, 2005.

[5] J. L. Sessler, E. Tomat, and V. M. Lynch, "Positive homotropic allosteric binding of silver(I) cations in a Schiff base oligopyrrolic macrocycle," Journal of the American Chemical Society, vol. 128, no. 13, pp. 4184-4185, 2006.

[6] S. Das, A. Nag, D. Goswami, and P. K. Bharadwaj, "Zinc(II)- and copper(I)-mediated large two-photon absorption cross sections in a bis-cinnamaldiminato Schiff base," Journal of the American Chemical Society, vol. 128, no. 2, pp. 402-403, 2006.

[7] K. Singh, M. S. Barwa, and P. Tyagi, "Synthesis and characterization of cobalt(II), nickel(II), copper(II) and zinc(II) complexes with Schiff base derived from 4-amino-3-mercapto6-methyl-5-oxo-1,2,4-triazine," European Journal of Medicinal Chemistry, vol. 42, no. 3, pp. 394-402, 2007.

[8] T. Rosu, M. Negoiu, S. Pasculescu, E. Pahontu, D. Poirier, and A. Gulea, "Metal-based biologically active agents: synthesis, characterization, antibacterial and antileukemia activity evaluation of $\mathrm{Cu}(\mathrm{II}), \mathrm{V}(\mathrm{IV})$ and $\mathrm{Ni}(\mathrm{II})$ complexes with antipyrine-derived compounds," European Journal of Medicinal Chemistry, vol. 45, pp. 774-781, 2010.

[9] G. Rajendran and G. S. Sreeletha, "Synthesis, characterization and antimicrobial studies of some mixed ligand complexes of lanthanide(III) ions," Asian Journal of Chemistry, vol. 14, no. 34, pp. 1639-1645, 2002.

[10] Y. Zheng, J. Lin, Y. Liang et al., "A novel terbium (III) betadiketonate complex as thin film for optical device application," Materials Letters, vol. 54, no. 5-6, pp. 424-429, 2002.

[11] N. Raman, A. Kulandaisamy, A. Shunmugasundaram, and K. Jeyasubramanian, "Synthesis, spectral, redox and antimicrobial activities of Schiff base complexes derived from 1-phenyl-2,3dimethyl-4-aminopyrazol-5-one and acetoacetanilide," Transition Metal Chemistry, vol. 26, no. 1-2, pp. 131-135, 2001.

[12] T. Rosu, E. Pahontu, C. Maxim, R. Georgescu, N. Stanica, and A. Gulea, "Some new $\mathrm{Cu}(\mathrm{II})$ complexes containing an $\mathrm{ON}$ donor Schiff base: synthesis, characterization and antibacterial activity," Polyhedron, vol. 30, pp. 154-162, 2011.

[13] A. Furst and R. T. Haro, Progress in Experimental Tumor Research, vol. 12, p. 102, 1969.

[14] F. Borges, C. Guimarães, J. L. F. C. Lima, I. Pinto, and S. Reis, "Potentiometric studies on the complexation of copper(II) by phenolic acids as discrete ligand models of humic substances," Talanta, vol. 66, no. 3, pp. 670-673, 2005.

[15] A. M. Khedr, A. A. El-Bindary, and A. M. Abd El-Gawad, "Stereochemistry of new nitrogen-containing heterocyclic compounds 14. Potentiometric and thermodynamic studies of 5-(phenylazo)-8-hydroxyquinolines and their metal complexes," Chemical Papers, vol. 59, no. 5, pp. 336-342, 2005.

[16] A. A. Al-Sarawy, A. A. El-Bindary, A. Z. El-Sonbati, and M. M. Mokpel, "Potentiometric and thermodynamic studies of azosulfonamide drugs," Polish Journal of Chemistry, vol. 80, no. 2, pp. 289-295, 2006.

[17] A. T. Mubarak, A. S. Al-Shihri, H. M. Nassef, and A. A. El-Bindary, "Potentiometric and thermodynamic studies of vanillin and its metal complexes," Journal of Chemical and Engineering Data, vol. 55, no. 12, pp. 5539-5542, 2010.

[18] A. T. Mubarak and A. A. El-Bindary, "Potentiometric and thermodynamic studies of 4-(1 H -Indol-3-yl)butanoic acid and its metal complexes," Journal of Chemical and Engineering Data, vol. 55, no. 12, pp. 5543-5546, 2010.

[19] G. G. Mohamed, M. M. Omar, and A. A. Ibrahim, "Biological activity studies on metal complexes of novel tridentate Schiff base ligand. Spectroscopic and thermal characterization," European Journal of Medicinal Chemistry, vol. 44, no. 12, pp. 4801-4812, 2009.

[20] G. H. Jeffery, J. Bassett, J. Mendham, and R. C. Deney, Vogel's Textbook of Quantitative Chemical Analysis, Longman, London, UK, 5th edition, 1989.

[21] R. G. Bates, M. Paabo, and R. A. Robinson, "Interpretation of pH measurements in alcohol-water solvents," Journal of Physical Chemistry, vol. 67, no. 9, pp. 1833-1838, 1963.

[22] H. M. Irving, M. G. Miles, and L. D. Pettit, "A study of some problems in determining the stoicheiometric proton dissociation constants of complexes by potentiometric titrations using a glass electrode," Analytica Chimica Acta, vol. 38, pp. 475-488, 1967.

[23] H. M. Irving and H. S. Rossotti, "The calculation of formation curves of metal complexes from $\mathrm{pH}$ titration curves in mixed solvents," Journal of the Chemical Society, pp. 2904-2910, 1954.

[24] H. Irving and H. S. Rossotti, "Methods for computing successive stability constants from experimental formation curves," Journal of the Chemical Society, pp. 3397-3405, 1953.

[25] F. J. C. Rossotti and H. S. Rossotti, Acta Chemica Scandinavica, vol. 9, pp. 1166-1176, 1955.

[26] M. T. Beck and I. Nagybal, Chemistry of Complex Equilibrium, Wiley, New York, NY, USA, 1990.

[27] M. M. Khalil, A. M. Radalla, and A. G. Mohamed, "Potentiometric investigation on complexation of divalent transition metal ions with some zwitterionic buffers and triazoles," Journal of Chemical and Engineering Data, vol. 54, no. 12, pp. 3261-3272, 2009.

[28] P. Sanyal and G. P. Sengupta, "Potentiometric studies of complex formation of some trivalent rare earths with p,p'bromosulphonosalicylidene anil," Journal of the Indian Chemical Society, vol. 67, no. 4, pp. 342-344, 1990.

[29] S. Sridhar, P. Kulanthaipandi, P. Thillaiarasu, V. Thanikachalam, and G. Manikandan, "Protonating and chelating efficiencies of some biologically important thiocarbonohydrazides in $60 \%(\mathrm{v} / \mathrm{v})$ ethanol-water system by potentiometric and spectrophotometric methods," World Journal of Chemistry, vol. 4, pp. 133-140, 2009.

[30] V. D. Athawale and V. Lele, "Stability constants and thermodynamic parameters of complexes of lanthanide ions and $( \pm)$ norvaline," Journal of Chemical and Engineering Data, vol. 41, no. 5, pp. 1015-1019, 1996.

[31] V. D. Athawale and S. S. Nerkar, "Stability constants of complexes of divalent and rare Earth metals with substituted salicynals," Monatshefte fur Chemie, vol. 131, no. 3, pp. 267-276, 2000.

[32] G. A. Ibañez and G. M. Escandar, "Complexation of cobalt(II), nickel(II), and zinc(II) ions with mono and binucleating azo 
compounds: a potentiometric and spectroscopic study in aqueous solution," Polyhedron, vol. 17, no. 25-26, pp. 4433-4441, 1998.

[33] W. U. Malik, G. D. Tuli, and R. D. Madan, Selected Topics in Inorganic Chemistry, S. Chand \& Company LTD, New Delhi, 3rd edition, 1984.

[34] F. R. Harlly, R. M. Burgess, and R. M. Alcock, Solution Equilibria, Ellis Harwood, Chichester, UK, 1980.

[35] L. E. Orgel, An Introduction to Transition Metal Chemistry Ligand Field Theory, Methuen, London, 1966.

[36] A. Bebot-Bringaud, C. Dange, N. Fauconnier, and C. Gerard,

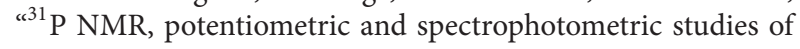
phytic acid ionization and complexation properties toward $\mathrm{Co}^{2+}, \mathrm{Ni}^{2+}, \mathrm{Cu}^{2+}, \mathrm{Zn}^{2+}$ and $\mathrm{Cd}^{2+}$, Journal of Inorganic Biochemistry, vol. 75, pp. 71-78, 1999.

[37] A. A. Al-Sarawy, A. A. El-Bindary, A. Z. El-Sonbati, and T. Y. Omar, "Potentiometric and thermodynamic studies of 3-(4methoxyphenyl)-5- azorhodanine derivatives and their metal complexes with some transition metals-14," Chemical Papers, vol. 59, no. 4, pp. 261-266, 2005.

[38] A. T. Mubarak, A. Z. El-Sonbati, and A. A. El-Bindary, "Potentiometric and conductometric studies on the complexes of some transition metals with rhodanine azosulfonamide derivatives-11," Chemical Papers, vol. 58, no. 5, pp. 320-323, 2004. 

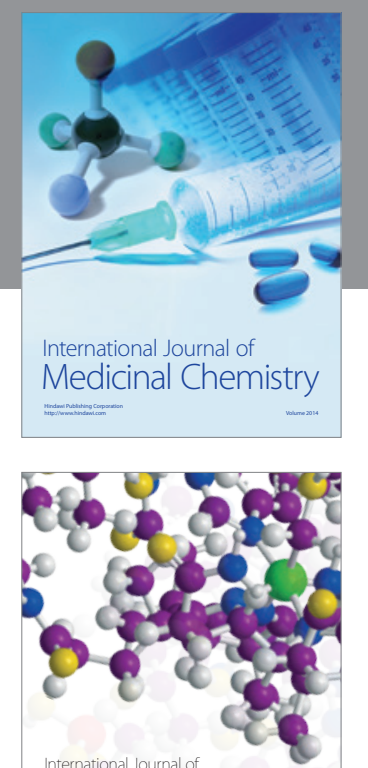

\section{Carbohydrate} Chemistry

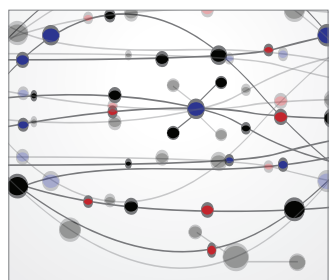

The Scientific World Journal
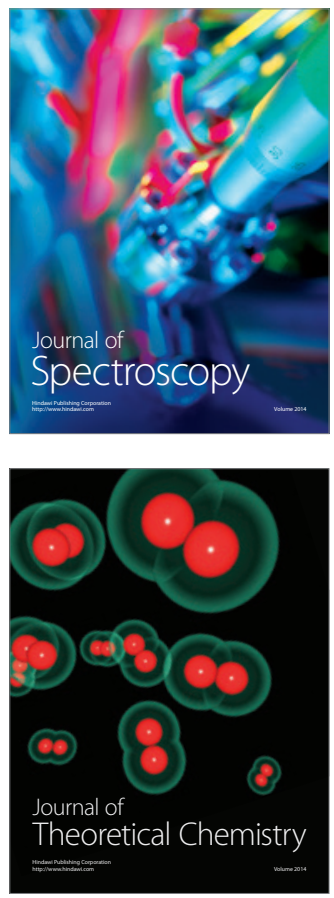
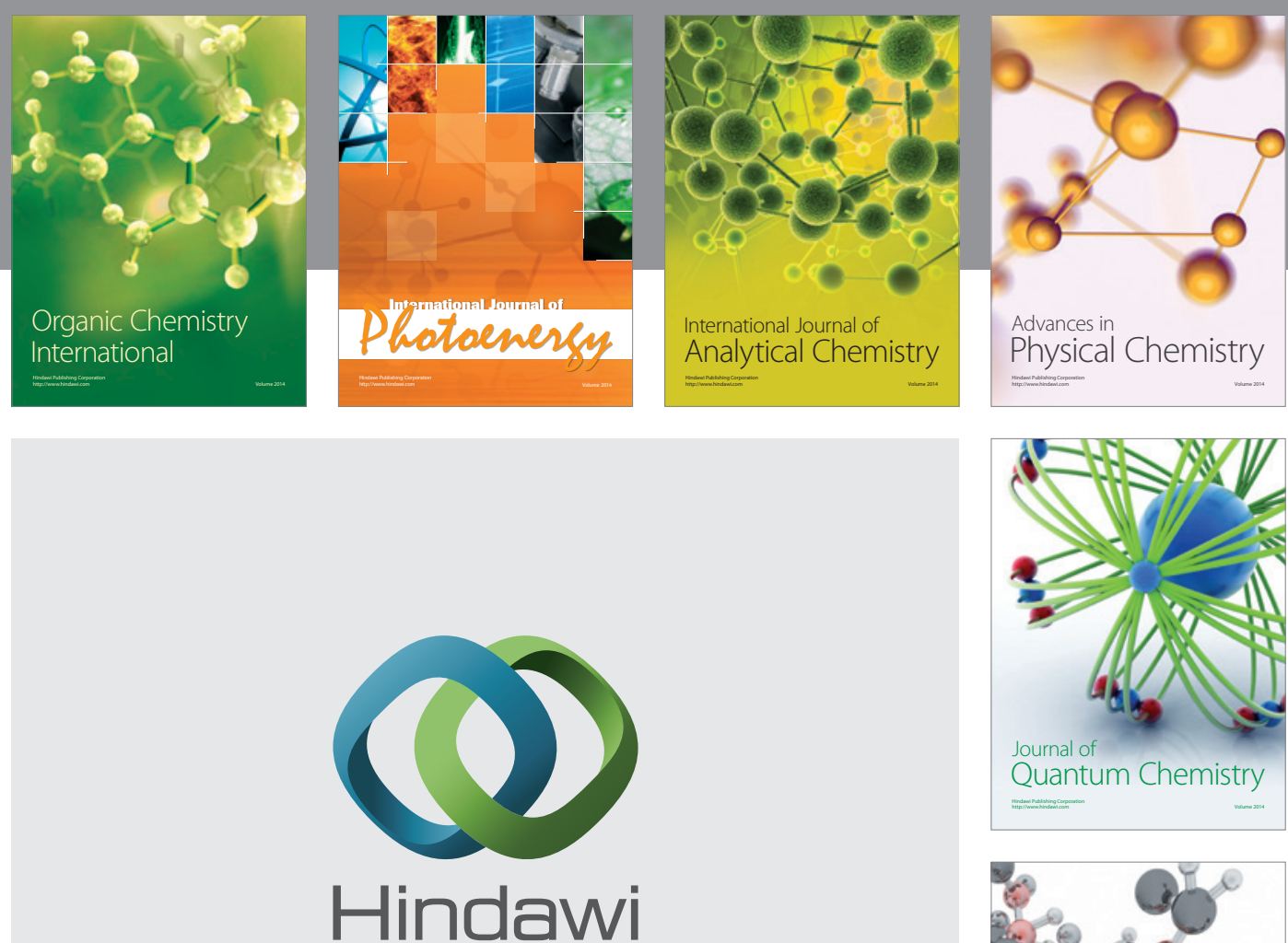

Submit your manuscripts at

http://www.hindawi.com

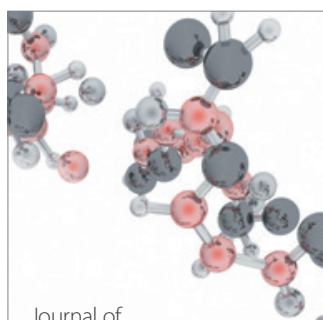

Analytical Methods

in Chemistry

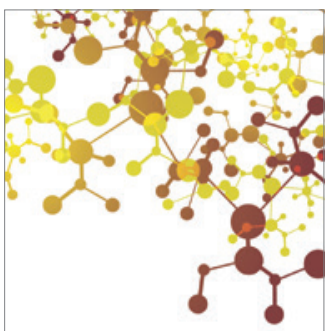

Journal of

Applied Chemistry

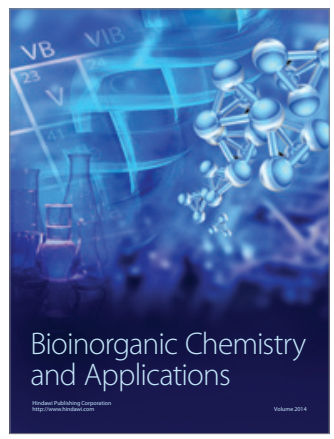

Inorganic Chemistry
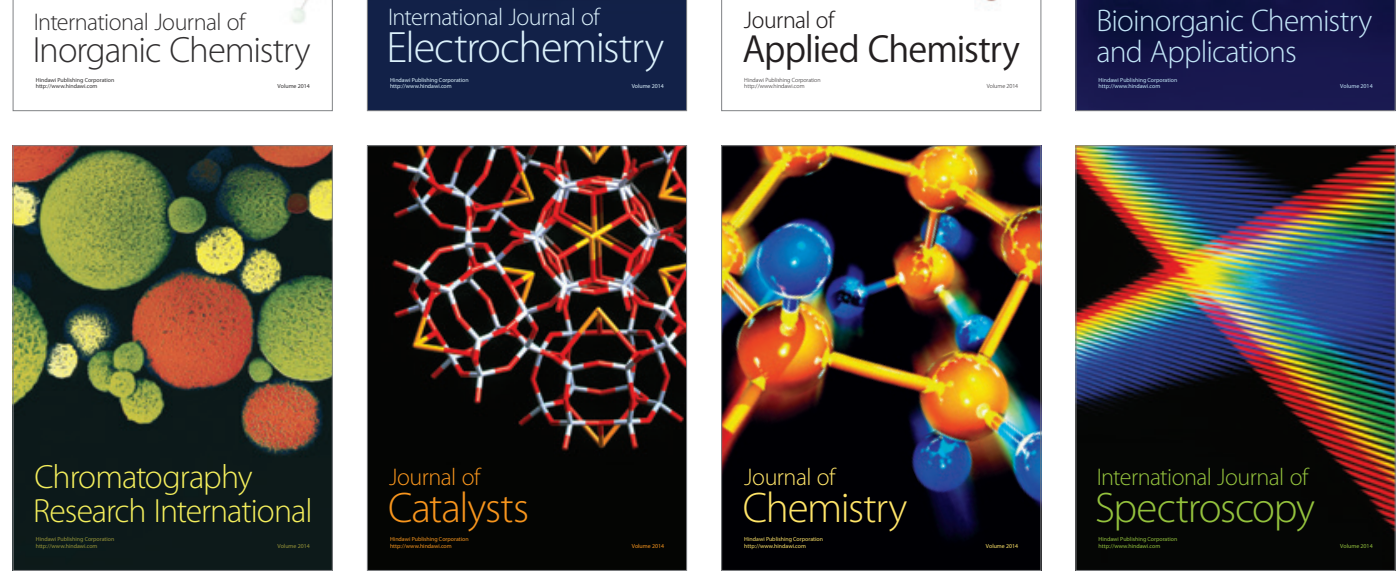